\title{
Democracy, Globalization, and Private Investment in Ghana
}

\author{
Samuel Kwabena Obeng ${ }^{1}$, Linda Akoto ${ }^{2}$, and Felicia Acquah ${ }^{3}$
}

\begin{abstract}
The paper examines the effect of democracy and globalization on private investment in Ghana for the period 1980-2012, using the Autoregressive Distributed Lag (ARDL) bounds test for cointegration and the Error Correction Model (ECM). Two models are used. In Model 1, democracy is proxy by an index for institutional quality (Polity2) while Model 2 uses an index for civil liberties as proxy for democracy. The results for model 1 shows globalization and public investment increase private investment while exchange rate volatility and trade openness decrease private investment in both the long-and short-run. In addition, economic growth and interest rate reduce private investment in the short-run. In the case of model 2, credit to the private sector and public investment increase private investment while exchange rate volatility and trade openness decrease private investment in both the long-and short-run. Finally, economic growth and interest rate reduce private investment in the short-run. The findings and policy recommendations of the paper provide vital information for policy implementation in Ghana.
\end{abstract}

Keywords: democracy, globalization, private investment, ARDL, ECM

\footnotetext{
${ }^{1}$ Corresponding Author: Department of Economics, Kwame Nkrumah University of Science and Technology (KNUST), Kumasi, Ghana, Email: sammyatom2007@yahoo.com Tel. +233 (0) 246219421

${ }^{2}$ Department of Economics, Kwame Nkrumah University of Science and Technology (KNUST), Kumasi, Ghana, Email: akotol@ymail.com

${ }^{3}$ Records and Archives Department, National Investment Bank (N.I.B.) Ltd., P.O. Box GP 3726, Accra. Email: feliciaacquah88@yahoo.com
} 


\subsection{Introduction}

Private investment is considered the engine of economic growth (Frimpong and Marbuah, 2010). This is because the private sector is deemed relatively more efficient in allocating resources compared to the public sector. In addition, there is less wastage in the private sector. Also, due to constant monitoring and evaluation, productivity in the private sector is assured. Finally, competition arises from the desire to maximize profits which eventually leads to increased consumer welfare (see Nickell, 1996; Porter, 1998, 2000; Rodrik, D, 2006). It is therefore not surprising that most notable industrializations in history have been led by the private sector (McDade and Spring, 2005).

Private investment is mostly viewed to be determined by factors such as interest rates, exchange rate volatility, economic growth, public investment, inflation, trade openness, among others. Recently, however, democracy and globalization are becoming important determinants of private investment. Interestingly, it is easier to assume and argue a positive effect of democracy on private investment even though this is more likely to be a desired outcome which may differ from evidence provided by an empirical investigation of the relationship between democracy and private investment. However, the effect of globalization on private investment largely remains unclear as it can be positive or negative (see Mamman et al., 2009). It therefore becomes necessary to investigate the effects of democracy and globalization on private investment.

Given this, the current paper examines the effect of democracy and globalization on private investment in Ghana. It differs significantly from other studies on Ghana. For instance, Eshun et al. (2014) strictly examines the financial determinants of private investment in Ghana for the period 1970-2010. Eshun et al. (2014) therefore makes use of variables such as real interest rate, credit to the private sector, real exchange rate, broad money supply, inflation rate and GDP. The current paper however considers variables that measure the nature of the financial system, the availability of imported capital and its associated exchange rate, macroeconomic instability and uncertainty, the extent of public participation in the domestic financial market, as well as the overall level of economic growth. In addition, unlike Frimpong and Marbuah (2010), the current paper considers among others globalization, exchange rate volatility, and public investment in explaining the determinants of private investment. The current paper also makes use of an institutional measure (Polity2) and a measure for civil liberties as proxy for democracy as against a dummy variable for constitutional regime used by Frimpong and Marbuah (2010) as proxy for democracy. It is also important to state that the current paper is the first attempt at modeling the effect of democracy and globalization on private investment in Ghana. The findings from the current paper are therefore uniquely different from those of the similar studies stated.

The rest of the paper is sectioned as follows: The next section reviews theoretical literature on the relationship between democracy and private investment, and globalization and private investment. It also reviews empirical literature on the subject matter being considered. The objectives and the rationale of the study are given in Sections 3 and 4 respectively. The model adopted, the data type and sources, the estimation strategy, as well as the model diagnostic and stability tests conducted are discussed in Section 5. Section 6 provides and analyzes the 
empirical results obtained. Finally, conclusions are given in Section 7, while implications and suggestions for future research are provided in Section 8.

\subsection{Review of Literature}

\subsection{Democracy and private investment}

Private investment is easier in a society where people are free to own property (Goldsmith, 1995). It is further encouraged by the presence of rule of law. Further, the judicial system must be efficient, easily accessible and also considered free, fair, and just (see Feng, 2001; Stasavage, 2002). Private investment will also increase when rules of entry and exit are 'reasonable' and 'sustainable'. Moreover, in order to attract foreign investment, laws regulating repatriation of profits must be fair ( $\mathrm{Li}, 2009)$. Labour laws must also protect the rights of both employers and employees. Hence, 'needless' and 'unnecessary' strikes and worker agitations must not be present. Added to this, the absence of political instability, threats of civil revolts and unrests, and hooliganism encourages private investment. Also, a country with few incidences of government take-over of private firms is more likely to attract and retain private investments (Gehlbach and Keefer, 2011). Private investment is also enhanced by the presence of effective and efficient institutions. This is because quality institutions are associated with less bureaucracy, red-tapeism, corruption, and rent-seeking activities. Therefore, innovation and resource allocation become easier (Aidt, 2009). Hence, democracy enhances private investment (see Pastor and Hilt, 1993; Helliwell, 1994; and Pastor and Sung, 1995). Finally, there are also arguments that, in any democratic economy, there might be motivations to obtain capital for private investment, mostly if the average voter has reasonably less capital than a regular person (see Persson and Tabellini, 1990; Dornbusch and Edwards, 1991; Alesina and Perotti, 1994).

Notwithstanding, there exists a theoretical argument for a negative relationship between democracy and private investment. This is based on two major principles. The first is that, democracy stimulates an urge for current consumption, hence reducing the 'resource pool' from which future savings can be made (Dominguez and Huntington, 1975). Secondly, social equality (democracy) causes the redistribution of the income of the median voter towards the poor. This may create increased consumption as against savings, possibly depriving investors the resources to fund private investment (may not be an absolute case though). Finally, the political institution of an economy may also be in no way inclined towards promoting private investment.

In the face of all the arguments, a positive relationship between democracy and government spending is posited. This is because, firstly, it must be stated that, the arguments for a negative relationship between democracy and investment is based on the premise that democracy has a political nature. This premise is not likely to hold given the fact that any political system requires social support to achieve an efficient and secure political environment. Hence, even though autocracy might appear to provide government stability, in reality it falls-short of the social foundation for a stable regime. On the other hand, policy regulation under a democratic

government ensures such governments are accountable and less arbitrary in taking decisions that are likely to have dire long-term consequences on private investment. Therefore, between an 
autocratic government and a democratic government, private investors would prefer the latter since it at least provides a stable environment for investment.

\subsection{Globalization and private investment}

Globalization also has implications for private investment. The complexities of regionalism and market integration are gradually turning the global economy into a 'spaghetti bowl' (Majluf, 2004). Bigger markets for goods and services are being created. In addition, domestic competition among firms in industrialized nations is causing investors to seek investment opportunities outside their home countries (Porter, 1998). This becomes necessary in cases where raw materials and other needed factors of production may either be non-existent or insufficient in the producer's home country. Such necessary raw materials may have to be imported. Alternatively, firms choose to create production chains in which different stages of producing a particular commodity are done in different countries (see Spencer, 2005; Baldwin, 2012; Amador and Cabral, 2014). The desire to explore and diversify investments may also cause investors to seek investment opportunities outside their home countries (see Ndikumana, 2000; Ghirmay, 2004; Mak et al., 2012). In the end, markets become diversified and this enables producers to access external markets. Moreover, globalization increases competition which improves production efficiency and consumer welfare. Finally, globalization encourages the diffusion of technology, improves infrastructure, enhances cooperation and learning processes, creates economies of scale, and ultimately causes economic growth (all these complement private investment).

From another perspective, it is possible for globalization to hinder private investment. For instance, firms in developed countries may damp goods on the markets of developing countries. This gradually kills initiative and innovation since firms in developing countries are mostly unable to produce to compete with damped goods from developed countries. The situation arises due to the fact that firms in developed countries use better production technology which added to other factors eventually makes their production costs relatively lower. Therefore, damped products are able to 'crowd-out' domestic goods and services (Van Biesebroeck, 2005). Unfortunately, strict rules of origin (may be non-trade, sanitary, phytosanitary, or more in nature) makes it difficult (if not impossible) for firms in developing countries to access the markets of developed countries even under preferential trade agreements (see Chutha and Kimenyi, 2011). The situation becomes more complex as the nature of the global market makes it less and less possible for governments in developing countries to restrict trade. The reason is that, developing countries are likely to suffer hugely from similar reciprocal restrictions from developed countries. This cripples domestic industries and hampers import-substitution drives.

Given the arguments above, the paper posits that the effect of globalization on private investment is unclear. 


\subsection{Determinants of Private Investment: A Survey}

The study discusses empirical literature on the determinants of private investment under two subheading; time series studies and panel data studies.

\subsubsection{Time-series studies}

Dailami and Walton (1992) using Johansen multivariate cointegration technique and the error correction model finds that public investment, gross national product, interest rate and exchange rate are positively related with private investment in Zimbabwe whereas wages, yields on governmental bonds and the price of capital goods showed a negative effect on private investment for the period 1970-1990. Oshikoya (1992) employing the autoregressive distributed lagged (ARDL) method for the period 1970-1989 shows that interest rate and public investment have a positive long-run effect on private investment while inflation, terms of trade and debt repayment are negatively related with private investment in Kenya. In a similar study, Asante (2000) finds that whereas private sector credit, public sector investment, exchange rate and interest rate positively influenced Ghana's private investment in the long-run, economic instability, political instability and economic growth impacted private investment negatively. The study made use of the Johansen multivariate cointegration technique and also covered the period 1970-1992. Employing the Engle-Granger two step approach to cointegration and the Johansen multivariate cointegration technique, Ribeiro (2001) states that except for exchange rate which had an adverse effect on private investment, public investment and output levels positively influenced private investment in Brazil for the period 1956-1996. Using, the Johansen cointegration technique on annual data sampled for Ghana for the period 1970-1994, Akpalu (2002) indicates that the key determinants of private investment in Ghana include, credit availability, public investment, real per capita income growth and cost of capital. However, cost of capital had an adverse effect on private investment in both the long-and short-run. Ouattara (2004) employs the ARDL approach to cointegration to investigate the principal drivers of private investment in Senegal for the period 1970-2000. The paper finds that public investment and national income positively influenced private investment whereas credit availability to the private sector, terms of trade and foreign aid had negative impact on private investment. Narayan (2008) using computable general equilibrium (GCE) models states that democracy, real GDP, real national welfare, government revenue, trade balance, private consumption and disposable income are the principal determinants of private investment in Fiji for the period 1972-2001.

Employing Engle-Granger cointegration techniques and the error correction model, Hassan and Salim (2011) finds that government expenditure, interest rate, and trade openness had negative effect on private investment in Bangladesh in the long-run for the period 1981-2003. However in the short-run, the effects of interest rate and trade openness on private investment were statistically insignificant. Naa-Idar et al., (2012) conducts a similar study on Ghana using Johansen multivariate cointegration technique and the error correction model and the results show that while economic growth, external debt, political stability, public investment, foreign aid, and credit to the private sector were positively related with private investment, exchange rate, inflation and trade openness showed a negative relationship. Ranjan and Kumar (2012) indicates public investment and foreign direct investment improve private investment in India but national income reduces private investment in both the long-and short-run. The study makes use of the Johansen multivariate cointegration technique and the error correction model, as well as data for the period 1990-2009. Using the Ordinary Least Square (OLS) estimation technique, Suhendra and Anwar (2014) shows that GDP growth rate, public investment, credit availability to the private sector and exchange rate stimulate private investment in Indonesia. The paper further indicates however that interest rate and inflation had negative effect on private 
investment in Indonesia. The paper considered the period 1990-2011 as the study period. Augustine (2014) investigates the determinants of private investment in Ghana using the ARDL technique within the framework of the error correction model. The study covered the period 1970-2011. The paper finds that in the long-run, GDP and exchange rate positively influenced private investment while inflation, public investment, real interest rate and the presence of a military regime had insignificant impact on private investment. Also from the study, exchange rate was found to have a positive effect on private investment in Ghana in the short-run while interest rate is seen to reduce private investment in Ghana in the short-run.

\subsubsection{Panel data studies}

Greene and Villanueva (1991) employs panel estimation techniques on a sample of 23 developing countries for the period 1975-1987 and finds that GDP growth, per capita GDP and investment by the public sector had positive impact on private investment. The paper however indicates that, interest rate, domestic inflation, debt-service ratio and external debt had negative effect on private investment. Servén (1998) indicates that exchange rate volatility and inflation deteriorates private investment whereas GDP growth rate, cost of capital, and terms of trade improved private investment for selected developing countries. The paper makes use of panel data estimation techniques for the period 1960-1995. Bleaney and Greenaway (2001) employs the fixed effect model on a panel of sub-Saharan African countries for the period 1980-1995 and shows that exchange rate volatility impedes private investment whereas terms of trade enhances private investment. Using the Generalized Method of Moments (GMM) estimation technique on 61 selected developing countries for the period 1970-1995, Servén (2003) states that exchange rate and exchange rate volatility adversely affects private investment. Similarly, Erden and Holcombe (2005) employs panel estimation techniques on a panel of 19 selected developing countries for the period 1980-1997 and finds that public investment and credit availability positively influenced private investment in the long-and short-run while real interest rate was found to have a negative effect on private investment in both the long-and short-run. The paper further stated that macroeconomic uncertainty had a negative effect on private investment in both the long-and short-run, even though the coefficient for the latter period was not statistically significant. Uneze (2010) shows that multilateral aid, GDP, and export growth improves private investment while bilateral aid and debt service hinders private investment in West Africa. The paper employs panel estimation techniques on data for the period 1975-2004. Munthali (2012) employs the fixed effect and random effect estimation techniques on data from Southern African countries for the period 1970-2012 and the results shows that, GDP and availability of capital have positive effects on private investment while exchange rate and cost of capital have negative effect on private investment.

It is obvious from the empirical literature reviewed that factors that determine private investment have been widely examined. Notwithstanding, gaps still remain. Firstly, the relevance of globalization to determining private investment is yet to be given adequate empirical attention. Secondly, even though some studies include democracy in examining the determinants of private investment, the approach used by the current study differs from those of previous studies. Specifically, for the empirical literature reviewed, where democracy was considered, it was proxy by political instability or the presence of military regime (see Asante, 2000; Augustine, 2004; Naa-Idar et al., 2012). The current study however proxy democracy by an index of institutional quality and an index of civil liberties. It must be stated that even though Narayan (2008) combines political rights and civil liberties into a single indicator of democracy, the measures of democracy used in the current paper remain different. Hence, the current paper 
attempts to fill the gap in the literature by including democracy and globalization as determinants of private investment.

\subsection{Objectives}

The current paper empirically examines the effect of democracy and globalization on private investment in Ghana. It also includes credit to the private sector, economic growth, inflation, exchange rate volatility, public investment and trade openness as other explanatory variables.

\subsection{Rationale of the study}

Ghana is widely considered a beacon of democracy on the African continent in general, and in the Sub-Saharan Africa, to be specific. The nation is also increasingly integrating with the rest of the world since the Structural Adjustment Programme (SAP) (see Sowa, 2002). Moreover, Ghana hugely desires private-sector-led industrialization (GIPC, 2015). It therefore becomes imperative to investigate the implications of democracy and globalization for private investment in Ghana.

\subsection{Methodology}

\subsection{Theoretical framework}

Models used to explain investment for developed countries typically follow a 'stock' or a 'flow' method as shown by Abel (1990). The 'stock' approach which is described by the 'flexible accelerator' method (the neoclassical approach) assumes private investment to be dependent on the price of capital as well as the rate of depreciation. On the other hand, the 'flow' approach argues private investment is determined by a convex function which measures the overall cost (given by output units) of reaching the desired levels of total investments. These theories may however not be able to fully explain private investment in developing countries (see Agénor and Montiel, 2008). Hence, it may be necessary to modify their arguments in order to fit prevailing conditions in developing countries. Examples of such conditions include the nature of the financial system, the availability of imported capital and its associated exchange rate, as well as macroeconomic instability and uncertainty. Other conditions such as the extent of public participation in the domestic financial market and the overall level of economic growth also determine private investment in developing countries. Hence, the theoretical framework adopted by this paper largely follows arguments put forward by Agénor and Montiel (2008) on these conditions.

Where the financial market is underdeveloped (for example, equity markets may be absent while corporate bond markets may also be limited), availability and affordability of credit is likely to be limited. This hinders private investment. Also, private investment in developing countries (particularly Africa) is highly influenced by credit availability as well as credit rationing (see Mlambo and Oshikoya, 2001). Hence, if credit is not available or is available but rationed, it hinders private investment. It must however be explained that credit to the private sector may typically be reflected by private demand for credit as against rationing of credit supply. Therefore, credit availability may not necessarily be limited by credit rationing (see Agénor and Montiel, 2008). 
Since firms are likely to depend on imported capital for investment, the price of the domestic currency as well as the availability of the imported goods become important determinants of private investment. The situation is not different for developing countries. For instance, Nucci and Pozzolo (2001) indicate depreciation in the real exchange rate can have contrasting effect on private investment. It may increase private investment by increasing investment revenues or decrease private investment through higher investment costs. The net effect may therefore be ambiguous as it is determined by the ratio of foreign supply to total supply and the level of dependence on imported inputs (see Servén, 1990; and Agénor and Montiel, 2008). Finally, the extent of openness of the economy to trade will also determine the degree of access to imported capital for investment.

The extent of public sector investment also determines private investment in developing countries. Where public investment is hindered by huge debt overhang (Clements et al., 2003) and debt servicing (see Cohen, 1993), it fails to complement private investment. It rather crowdsout private investment. The reason is that, the public sector investment may be making use of scarce financial and physical resources which might have been available for use by the private sector. The source of financing for public investment (taxes, debt instruments such as Treasury bills, and inflation as against concessional foreign lending) is also likely to either crowd-out or crowd-in private investment. Where the government is involved in the direct production of goods and services, demand for private goods may also be affected which is likely to affect private investment. Finally, it is necessary to consider the crowding-out-crowding-in effect of public investment as governments in developing countries are mostly the providers of major infrastructure (see Agénor and Moreno-Dodson, 2007).

Macroeconomic instability and uncertainty also determines private investment in developing countries. This may be explained by the degree and consistency of general economic growth, the levels and stability of changes in general prices (inflation), exchange rate volatility, interest rates, as well as political factors. Uncertainties caused by political factors increase investment risk factors, which may create uncertainties with regard to expected returns on investment. Investment will be discouraged while capital flight increases (see Alesina and Tabellini, 1989). Uncertainties may also be created by external (global) conditions since most developing countries are import-dependent added to the fact that the global economy is gradually forming a 'spaghetti bowl' with both developed and developing countries dependent on each other. Besides, macroeconomic instability characterized by unstable exchange rates, increasing interest rates and inflation rates may not provide an environment considered investment-friendly since they are likely to increase investment risks and uncertainties.

Following the arguments above and adopting a typical Cobb-Douglas production function, the paper argues private investment in a developing country to be determined as follows: 
$P I=$ private investment

$r=$ cost of capital

$K=$ the nature of the financial system

$Z=$ macroeconomic factors

$V=$ uncertainties

$C=$ role of public capital (public investment)

$M=$ "ability" to import inputs

$W=$ scale parameter

$\tau, \beta, \gamma, \delta, \rho$, and $\lambda$ are the parameters of the variables.

Hence, in the case of the current study, the paper specifies cost of capital, the nature of the financial system, macroeconomic factors, uncertainties, role of public capital, and "ability" to import inputs to be determined as follows:

$r=f(R)=$ Lending interest rate

$K=f(C R E D)=$ Credit to the private sector

$Z=f(G D P, I N F, e r v)=$ Economic growth, inflation and exchange rate volatility respectively (4)

$V=f(D E M, G L O B)=$ Democracy and globalization respectively

$C=f(G F C F)=$ Gross fixed capital formation (public investment)

$M=f(T O)=$ Trade openness

Putting equations (2) - (7) into equation (1) produces:

$$
P I=W R^{\tau} C R E D^{\beta} G D P^{\gamma_{1}} I N F^{\gamma_{2}} \operatorname{erv}^{\gamma_{3}} D E M^{\delta_{1}} G L O B^{\delta_{2}} G F C F^{\rho} T O^{\lambda} \varepsilon^{\mu}
$$


The paper log-linearizes equation (8) and introduces time to show the time variant nature of the variables to produce:

$\ln P I_{t}=\alpha_{0}+\alpha_{1} \ln R_{t}+\alpha_{2} \ln C R E D_{t}+\alpha_{3} \ln G D P_{t}+\alpha_{4} \ln I N F_{t}+\alpha_{5} e r v_{t}+\alpha_{6} D E M_{t}+\alpha_{7} G L O B_{t}+\alpha_{8} \ln G F C F_{t}+\alpha_{9} \ln T O_{t}+\mu_{t}$

Where $\alpha_{0}=\ln W$ is the constant term, $\alpha_{1}=\tau, \alpha_{2}=\beta, \alpha_{3}=\gamma_{1}, \alpha_{4}=\gamma_{2}, \alpha_{5}=\gamma_{3}, \alpha_{6}=\delta_{1}$, $\alpha_{7}=\delta_{2}, \alpha_{8}=\rho$ and,$\alpha_{9}=\lambda$ and are parameters of the variables. The error term is represented by $\mu_{t}$ and $\ln$ represents the natural logarithm operator. $\alpha_{4}$ is expected to be negative and statistically significant while $\alpha_{2}, \alpha_{3}$, and $\alpha_{6}$ are expected to be positive and statistically significant. However, $\alpha_{1}, \alpha_{5}, \alpha_{7}, \alpha_{8}$, and $\alpha_{9}$ may have positive or negative relationship with private investment.

\subsection{Data sources and type}

Annual data for the period 1980-2012 is used. The dependent variable, PI, is measured as the private-sector gross fixed capital formation. Data on private investment is obtained from the World Bank, World Development Indicators (WDI, 2015). The current study makes use of the KOF overall globalization index (see Dreher, 2003; 2006; 2008) as measure of globalization. The overall index (denoted as $G L O B$ ) is made up of three important aspects of globalization; economic globalization, social globalization and political globalization. Economic globalization is made up of information on actual trade flows and restrictions. Social globalization includes data on personal contact, data on information flows, and data on cultural proximity. Political globalization is measured by membership in international organizations, signatory to international treaties, among others. The index of globalization considered here therefore provides a comprehensive measure comprising policy and 'physical' flows, making it an appropriate indicator for globalization. Democracy is measured by proxies for institutional quality (i.e. Polity2, $P T$ ) and Civil Liberties $(C L)$. Data on Polity2 is sourced from Polity IV Project (Marshall and Jaggers, 2014) while that on Civil Liberties is sourced from Freedom House (2014). Data on nominal exchange rate is obtained from the World Bank, World Development Indicators (WDI, 2015). The GARCH $(1,1)$ is then used to derive data on exchange rate volatility ( erv) from the nominal exchange rate values. Data on credit to the private sector ( $C R E D)$ is also sourced from the World Bank, World Development Indicators (WDI, 2015). Economic growth is proxy by real gross domestic product ( GDP). Public investment ( $G F C F$ ) is proxy by gross fixed capital formation. Inflation ( INF) as used here refers to the end year inflation rate. Trade openness is measured using the trade share in GDP (i.e. [Exports + Imports] / GDP). Interest rate $(R)$ is proxy by the lending interest rates on borrowed funds fixed by banks. Data on economic growth, public investment, inflation, trade openness, and interest rate are obtained from the World Bank, World Development Indicators (WDI, 2015). 


\subsection{Estimation strategy}

The paper investigates the stationarity properties of the variables in equation (2) using the parametric Augmented Dickey-Fuller (ADF) and the non-parametric Phillips-Perron (PP) test procedures (ADF and PP are due to Dickey and Fuller, 1979; 1981; and Phillips and Perron, 1988 respectively). This is to ensure that the variables are mean reverting and as such do not produce spurious results. The test is done at the levels and first difference, using a constant and a trend and a constant but no trend in each case.

Following the unit root test, the paper investigates the presence of a log-run relationship between the variables using the Autoregressive Distributed Lag (ARDL) bounds testing approach (see Pesaran et al., 2001). This methodology is appropriate for examining cointegration as it is able to make use of variables that are strictly $I(0)$ or $I(1)$ or a mix, provided such series are not $I(2)$ or more. It is also appropriate for time series studies that have smaller number of observations (33 in this case). By cointegration, the study examines whether in equilibrium there exists a link amongst the variables included in a particular model. The test procedure adopts the error correction model (ECM) framework and also makes use of the Wald/F-statistic. The use of the ECM framework is significantly important for an economic study since it accounts for how previous disequilibrium is corrected in current periods. Therefore, spurious results are avoided.

The ARDL model is stated as:

$$
\Delta Y_{t}=\beta_{0}+\sum_{i=1}^{k} \beta_{1} \Delta Y_{t-i}+\sum_{i=0}^{k} \beta_{n} \Delta X_{t-i}+\tau_{1} Y_{t-1}+\tau_{n} X_{t-1}+\mu_{t}
$$

The regressand and a vector of a series of explanatory variables in equation (9) are given by $Y_{t}$ and $X_{t}$ respectively. $n$ represents the number of regressors and $k$ implies the lag order. $\varepsilon_{t}$ is the error term and $\Delta$ is the difference operator. The lags of the independent and the dependent variables are given as $X_{t-1}$ and $Y_{t-1}$ respectively. $\beta_{n}$ represents the coefficient of the vector of independent regressors.

The test examines the null hypothesis of no levels relationship $\left(H_{0}: \tau_{1}=\tau_{n}=0\right)$ between the series in equation (2), against the alternative hypothesis of the presence of such relationship ( $H_{1}: \tau_{1} \neq \tau_{n} \neq 0$ ). The ARDL approach provides two bounds within which cointegration decisions are based. The upper bound assumes all series to be $I(1)$ while the lower bound assumes all series are $I(0)$. Given this, there is cointegration if the estimated F-statistic is greater than the upper bound critical value while no evidence of cointegration exists if the F-statistic estimated is less than the lower bound value. Where the F-statistic is found to be in between the lower and the upper bound values, inconclusive evidence for cointegration emerges. The presence of cointegration will make it appropriate to estimate and analyze long-and short-run relationship among the series in equation (2). 


\subsection{Model adequacy and reliability}

To ensure the estimations obtained are robust and reliable, a series of diagnostic and reliability tests will be conducted. The study examines normality using the Jarque-Bera test. Serial correlation and heteroscedasticity will be examined using Lagrange multiplier (LM) and the Breusch-Pagan-Godfrey tests respectively. Stability is tested using the CUSUM and the CUSUMSQ.

\subsection{Analysis}

\subsection{Unit root results}

The unit root test was done using the $\mathrm{ADF}$ and PP unit root test procedures to ascertain the stationarity properties of the variables used for the study. The results are presented in Table 1.

\section{INSERT TABLE 1 HERE}

From the results, the variables in equation (2) are either integrated of order zero (i.e. $I[0]$ ) or one (i.e. I[1]). This is irrespective of whether the test is done with a constant and trend or with a constant but with no trend. The results are also similar whether the test is done within the ADF or PP framework.

\subsection{Cointegration test results}

Given the unit root test results, it becomes appropriate to adopt the ARDL bounds test approach to cointegration to examine the presence of a long-run relationship among the variables. The cointegration results obtained using the ARDL bounds test method is given in Table 2. The ARDL $(1,0,0,0,1,1,0,1,0,0)$ and the ARDL $(1,0,0,0,1,1,0,1,0,0)$ are selected for Models 1 and 2 respectively. The selection is based on the Schwartz Bayesian Criterion (SBC). The SBC is used because it provides the most parsimonious results. The maximum lag length is 2 lags.

\section{INSERT TABLE 2 HERE}

From the results, the computed F-statistic for each model is greater than its respective upper bound critical value at 5 per cent level of statistical significance. The null hypothesis of no cointegration is therefore rejected. Hence, the variables in Models 1 and 2 are cointegrated.

\subsection{The estimated long-and short-run results}

The results for Models 1 and 2 are given in columns 2 and 3 respectively in Tables 3 and 4 . Long-run results are provided in Table 3 while short-run results are given in Table 4.

\subsubsection{Long-run}

\section{Model 1}

The results for Model 1 indicate globalization improves private investment in the long-run. This is because, the coefficient of the globalization variable (GLOB) is positive and statistically significant at 10 per cent level. The implication is that, private investment increases with globalization in Ghana. This is likely to be the situation if globalization attracts foreign 
investment, encourages diffusion of technology, and encourages cooperation and learning processes. This creates economies of scale and causes increased domestic competition which eventually drives private investment. The paper notes that Spencer (2005), Baldwin (2012), and Amador and Cabral (2014) indicate globalization increases private investment.

Also in Model 1, the coefficient of the exchange volatility variable ( $E R V)$ is negative and statistically significant at 1 per cent level. Exchange rate volatility therefore reduces private investment. This is not surprising as a volatile exchange rate increases uncertainty in relation to investment profits. This therefore serves as a disincentive for investment since for every investor, investment is a goal that targets an end of profit making. Firms that are heavily dependent on imports for inputs are likely to suffer hugely from such uncertainties which increase investment risks. In addition, exporters may also face uncertainties and increased risks with regards to expected returns on exports. Similar evidence of a negative relationship between exchange rate volatility and private investment is provided by Naa-Idar et al. (2012) for Ghana and Servén (2003) for some developing countries.

From the results, public investment increases private investment in the long-run. The reason is that a positive and statistically significant relationship is established between public investment and private investment. The coefficient of the public investment variable (GFCF) is significant at 1 per cent level. The implication is that, increasing public investment complements private investment since such increased public investment creates an investment-friendly environemnt. Ribeiro (2001), Ouattara (2004), Frimpong and Marbuah (2010) and Ranjan and Kumar (2012) confirm similar positive relationship between public investment and private investment in Brazil, Senegal, Ghana and India respectively.

The long-run coefficient of the trade openness variable (TO) in Model 1 is however negative and statistically significant at 10 per cent level of significance. This may be so if opening up the private sector to trade creates opportunities for damping which competes with locally produced goods and services, killing innovation and production. In the end, private investment is discouraged. Hassan and Salim (2011) provide similar evidence for Bangladesh.

It must be stated that for Model 1 , credit to the private sector, economic growth, inflation, and interest rate improve private investment in the long-run even though their coefficients are not statistically significant. Ouattara (2004), and Frimpong and Marbuah (2010) indicate credit to the private sector enhances private investment in Senegal and Ghana respectively, and Erden and Holcombe (2005) provides similar evidence for 19 developing countries. Frimpong and Marbuah (2010) provide similar evidence of a positive long-run relationship between economic growth and private investment in Ghana. The negative inflation-private-investment relationship confirms evidence provided by Akpalu (2002), Naa-Idar et al. (2012) and Augustine (2014) for Ghana. However, the long-run results for interest rate contradicts that of Badawi (2004), Hassan (2011), Augustine (2014) and Suhendra and Anwar (2014) for Sudan, Bangladesh, Indonesia and Ghana respectively. 
The long-run coefficient of the institutional quality variable ( $P T$ ) is negative and statistically insignificant. The implication is that, Ghana's existing institutions hinder private investment. This raises questions about the quality of the nation's institutions.

\section{INSERT TABLE 3 HERE}

\section{Model 2}

Generally, the long-run results for Model 2 confirm those for Model 1. However, in Model 2, credit to the private sector has a positive and statistically significant (at 10 per cent level) relationship with private investment in the long-run. Globalization improves private investment in the long-run, even though the coefficient is not statistically significant. Exchange rate volatility also has a negative and statistically significant relationship with private investment in the long-run. GDP improves private investment in the long-run even though the coefficient is not statistically significant. Public investment enhances private investment in the long-run and the coefficient is statistically significant at 1 per cent level. Inflation improves private investment in the long-run, even though the coefficient is not statistically significant. Interest rate improves private investment in the long-run. Trade openness reduces private investment in the long-run, and the coefficient is statistically significant at 5 per cent level. Also for Model 2, even though the long-run coefficient of the proxy for democracy (civil liberties) is positive, it is statistically insignificant. It can therefore be inferred that in the long-run there is likelihood for private investment to grow in Ghana if the citizenry continue to enjoy civil liberties.

\subsubsection{Short-run}

The result for the coefficient of the error correction term (ecm[-1]) for both models suggests the estimated models are reliable. This is because both coefficients are negative and statistically significant at 1 per cent level. This provides further evidence of cointegration relationship. Also, each coefficient is reasonably high in absolute value ( 0.80 and 0.82 respectively), implying high speed of adjustment in long-run equilibrium every year after a short-run shock. Specifically, for models 1 and 2 respectively, long-run equilibrium will adjust by approximately 80 and 82 per cent respectively every year after a short-run shock. Following this, the short-run coefficients are discussed.

\section{INSERT TABLE 4 HERE}

\section{Model 1}

In Model 1, the short-run coefficients of credit to the private sector, globalization, public investment, and inflation confirmed those of the long-run. They are all positive even though only the coefficients of globalization and public investment are statistically significant. The short-run coefficients of exchange rate volatility, trade openness, and institutional quality are however negative, even though the coefficient of the latter is not statistically significant. These coefficients confirm those of the long-run. 
However, the short-run coefficients of economic growth and interest rate contradict those of the

long-run. They are negative and statistically significant at 1 and 10 per cent respectively. Asante (2000) similarly states a negative short-run relationship between GDP and private investment in Ghana. Also, the short-run result for interest rate confirms the user cost of capital theory for Ghana. That is, rising interest rates increase the user cost of capital. This increases the cost of doing business and reduces potential levels of profit. Ultimately, it serves as a disincentive to private investment. Badawi (2004), Hassan and Salim (2011), Augustine (2014) and Suhendra and Anwar (2014) provide similar results for Sudan, Bangladesh, Indonesia and Ghana respectively.

\section{Model 2}

In the case of Model 2, the short-run coefficients of credit to the private sector, globalization, public investment, inflation and civil liberties confirm those of the long-run since they are all positive. However, only the coefficients of credit to the private sector and public investment are statistically significant at 10 and 1 per cent level respectively. The short-run coefficients of exchange rate volatility and trade openness are negative and statistically significant at 1 and 5 per cent level respectively, confirming those of the long-run.

Also in the short-run, the coefficients of economic growth and interest rate are negative and statistically significant at 5 and 10 per cent level respectively. Both results contradict those of the long-run. It must be stated that here also, the negative coefficient of the interest rate variable confirms the user cost of capital theory for Ghana.

\subsection{Model diagnostics and stability}

Both models pass all diagnostic and stability tests conducted, implying the models are robust and reliable. Specifically, the paper examined serial correlation, heteroscedasticity, and normality using the Lagrange multiplier (LM), Breusch-Pagan-Godfrey and the Jarque-Bera test respectively. Further, structural stability is tested using the cumulative sum (CUSUM) and cumulative sum of squares (CUSUMSQ) and the results indicate clearly that the estimated models are structurally stable. The model diagnostics and stability test results are given in Table 5 .

\section{INSERT TABLE 5 HERE}

\subsection{Conclusions}

The paper examines the effect of democracy and globalization on private investment in Ghana for the period 1980 to 2012. The autoregressive distributed lag (ARDL) bounds test approach to examining cointegration is adopted to estimate the results. This method is used since it is appropriate for small sample size studies and studies with variables that are integrated of order zero, one, or a mixture of both. Variables considered for the study are credit to the private sector, globalization, exchange rate volatility, economic growth (GDP), public investment, inflation, interest rate, trade openness, an index for institutional quality (Polity2), and an index for civil liberties. Two models are used. In Model 1, democracy is proxy by an index for institutional 
quality (Polity2) while Model 2 uses an index of civil liberties as proxy for democracy. From model 1, globalization and public investment increase private investment while exchange rate volatility and trade openness decrease private investment in both the long-and short-run. Economic growth and interest rate reduce private investment in the short-run. In the case of model 2, credit to the private sector and public investment increase private investment while exchange rate volatility and trade openness decrease private investment in both the long-and short-run. Finally, in model 2, economic growth and interest rate reduce private investment in the short-run.

\subsection{Implications/Future Research}

The paper recommends that policy makers ensure that public investments continually crowd-in private investment instead of crowding it out. In other words, public investment must complement private investment. To do this, there must be a trade-off between public investment and the cost of capital since the latter is the major determinant of the levels of investment. Hence, in the want of increasing private investment, policy makers must be cautious of the source of funding in order not to cause increases in interest rate. Given the negative relationship between exchange rate volatility and private investment, Bank of Ghana must put in place necessary policies to control frequent variations in exchange rate. This is necessary as exchange rate volatility increases uncertainty with regards to export earnings and the cost of imported inputs, which raises the levels of investment risks. It must be stated that due to the interrelationship between interest rate, inflation and exchange rate, policies targeted at controlling inflation for instance are likely to control exchange rate volatility. Finally, policy makers must ensure globalization attracts foreign investment, encourages diffusion of technology, and encourages cooperation and learning processes as this will create economies of scale and cause increased domestic competition which will eventually drive private investment and improve consumer welfare.

Notwithstanding the fact that none of the coefficients of the proxy for democracy used is statistically significant, the paper makes recommendations based on the findings. The negative coefficient of the institutional quality variable implies the current nature of Ghana's institutions hinder private investment. Policies must therefore be put in place to reduce bureaucracy, corruption, red-tapeism, nepotism and rent-seeking activities as doing so will improve institutional quality, reduce administration-related investment costs, and ultimately encourage private investment. Also, going forward, respect for civil liberties must be encouraged. For instance, private property rights must be fostered. The country must also ensure laws are free, enforced, fair, and easily accessible, and justice is assured, as these conditions enhance private investment.

Given the importance of the subject matter considered by this paper, the paper recommends that future studies consider panel data analysis of the subject matter examined here due to the possible limitations associated with time series studies. 


\section{Acknowledgment}

The authors are grateful to the anonymous referees of the journal for their extremely useful suggestions to improve the quality of the paper. Usual disclaimers apply.

We have also benefited from comments by Dr. (Mrs.) Grace Ofori-Abebrese, Department of Economics, Kwame Nkrumah University of Science and Technology (KNUST), Kumasi, Ghana.

\section{References}

Abel, A.B. (1990). Consumption and investment. In Handbook of Monetary Economics II, edited by Benjamin Friedman and Frank H. Hahn. Amsterdam: North Holland.

Agénor, P. R., and Montiel, P. J. (2008). Development macroeconomics. Princeton University Press.

Agénor, P.R., and Moreno-Dodson B. (2007). Public infrastructure and economic growth: New channels and policy implications. In Public Expenditure, edited by Maura Francese, Daniele Franco, and Raffaela Giordano. Rome: Banca d'Italia.

Aidt, T. S. (2009). Corruption, institutions, and economic development. Oxford Review of Economic Policy, 25(2), 271-291.

Akpalu, W. (2002). Modelling private investment in Ghana: An empirical time series econometrics investigation'. The Oguaa Journal of Social Sciences, Vol. 4.

Alesina, A., and Perotti, R. (1994). The political economy of growth: a critical survey of the recent literature. The World Bank Economic Review, 8(3), 351-371.

Alesina, A., and Tabellini, G. (1989). External debt, capital flight, and political risk. Journal of International Economics, 27(3): 199-220.

Amador, J., and Cabral, S. (2014). Global value chains: a survey of drivers and measures. Journal of Economic Surveys.

Asante, Y. (2000). Determinants of private investment behaviour (No. RP_100).

Augustine, K. (2014). Determinants of Private Sector Investment in Ghana, 1970-2011. Master Thesis submitted to the Kwame Nkrumah University of Science and Technology.

Badawi, A. (2004). Private capital formation and macroeconomic policies in Sudan: Application of a simple cointegrated vector autoregressive model, Department of Economics, University of Khartoum.

Baldwin, R. E. (2012). Global supply chains: Why they emerged, why they matter, and where they are going. 
Bleaney, M., and Greenaway, D. (2001). The impact of terms of trade and real exchange rate volatility on investment and growth in sub-Saharan Africa. Journal of development Economics, $65(2), 491-500$.

Chutha, R. N., and Kimenyi, M. S. (2011). The Africa Growth and Opportunities Act: Toward 2015 and Beyond: a Synthesis of Stakeholders' Views on the Future of US-Africa Commercial Relationships. Brookings Institution, Africa Growth Initiative.

Clements, B. J., Bhattacharya, R., and Nguyen, T. Q. (2003). External debt, public investment, and growth in low-income countries. Working Paper no. 03/249, International Monetary Fund.

Cohen, D. (1993). Low investment and large LDC debt in the 1980's. American Economic Review, 83, 437-49.

Dailami, M., and Walton, M. (1992). Private investment, government policy and foreign capital: a study of the Zimbabwean experience. Reviving Private Investment in Developing Countries.

Dickey, D.A., and Fuller, W.A. (1981). Likelihood ratio statistics for autoregressive time series with a unit root, Econometrica: Journal of the Econometric Society, pp. 1057-1072.

Dickey, David A., and Fuller, W.A. (1979). Distribution of the estimators for autoregressive time series with a unit root, Journal of the American Statistical Association, 74, No. 366a pp. 427431.

Dominguez, J. I., and Huntington, S. P. (1975). Political development, in 'Handbook of political science'. Reading, Mass, 3, 1-114.

Dornbusch, R., and Edwards, S. (1991). The macroeconomics of populism. InThe macroeconomics of populism in Latin America (pp. 7-13). University of Chicago Press.

Dreher, A. (2003). Does globalization affect growth?

Dreher, A. (2006). Does globalization affect growth? Evidence from a new index of globalization. Applied Economics, 38(10), 1091-1110.

Dreher, A., and Gaston, N. (2008). Has Globalization Increased Inequality?*.Review of International Economics, 16(3), 516-536.

Erden, L., and Holcombe, R. G. (2005). The effects of public investment on private investment in developing economies. Public Finance Review, 33(5), 575-602.

Eshun, M. E., Adu, G., and Buabeng, E. (2014). The financial determinants of private investment in Ghana (No. 57570). University Library of Munich, Germany.

Feng, Y. (2001). Political freedom, political instability, and policy uncertainty: A study of political institutions and private investment in developing countries. International Studies Quarterly, 45(2), 271-294. 
Freedom House (2014). Freedom in the World 2014: The Annual Survey of Political Rights and Civil Liberties. Rowman and Littlefield.

Frimpong, J. M., and Marbuah, G. (2010). The determinants of private sector investment in Ghana: An ARDL approach. European Journal of Social Sciences, 15(2), 250-261.

Gehlbach, S., and Keefer, P. (2011). Investment without democracy: Ruling-party institutionalization and credible commitment in autocracies. Journal of Comparative Economics, 39(2), 123-139.

Ghana Investment Promotion Centre (2015), Ghana Investment Promotion Centre (GIPC) Quarterly Report, Volume 11, Issue 3, Ghana Investment Promotion Council, Accra, Ghana.

Ghirmay, T. (2004). Financial development and economic growth in Sub-Saharan African Countries: Evidence from time series analysis. African Development Review, 16(3), 415-432.

Goldsmith, A. A. (1995). Democracy, property rights and economic growth. The Journal of Development Studies, 32(2), 157-174.

Greene, J., and Villanueva, D. (1991). Private investment in developing countries: an empirical analysis. Staff Papers-International Monetary Fund, 33-58.

Hassan A.F.M. K and Salim R. A. (2011). Determinants of private investment: Time series evidence from Bangladesh. The Journal of Developing Areas, Vol. 45 (Fall 2011), pp. 229-249

Helliwell, J. F. (1994). Empirical linkages between democracy and economic growth. British journal of political science, 24(02), 225-248.

Li, Q. (2009). Democracy, autocracy, and expropriation of foreign direct investment. Comparative Political Studies.

Majluf, L.A. (2004). Swimming in the spaghetti bowl: challenges for developing countries under the 'new regionalism'. Policy Issues in International Trade and Commodities, Study Series, No. 27.

Mak, A. H., Lumbers, M., and Eves, A. (2012). Globalization and food consumption in tourism. Annals of Tourism Research, 39(1), 171-196.

Mamman, A., Baydoun, N., and Liu, K. (2009). Exploring the meanings of globalization in Beijing. Global Business Review, 10(1), 67-86.

Marshall, M. G., and Jaggers, K. (2014). Polity IV Project: Political Regime Characteristics and Transitions, 1800-2009. Dataset Users' Manual. College Park: University of Maryland.

McDade, B. E., and Spring, A. (2005). The 'new generation of African entrepreneurs': networking to change the climate for business and private sector-led development. Entrepreneurship and Regional Development, 17(1), 17-42. 
Mlambo, K. and Oshikoya, T.W. (2001). Macroeconomic factors and investment in Africa. Journal of African Economies, 10(suppl 2), 12-47.

Munthali, T. C. (2012). Interaction of public and private investment in Southern Africa: a dynamic panel analysis. International Review of Applied Economics, 26(5), 597-622.

Naa-Idar, F., Ayentimi, D. T., and Frimpong Magnus, J. (2012). A time series analysis of determinants of private investment in Ghana (1960-2010). Journal of Economics and Sustainable Development, 3(13).

Narayan, P. K. (2008). An econometric model of the determinants of private investment and a CGE model of the impact of democracy on investment and economic growth in Fiji. International journal of social economics, 35(12), 1017-1031.

Ndikumana, L. (2000). Financial determinants of domestic investment in Sub-Saharan Africa: Evidence from panel data. World Development, 28(2), 381-400.

Nickell, S. J. (1996). Competition and corporate performance. Journal of political economy, 724746.

Nucci, F. and Pozzolo, A.F. (2001). Investment and the exchange rate: An analysis with firmlevel panel data. European Economic Review, 45(2), 259-83.

Oshikoya, T. W. (1992). Interest rate liberalization, savings, investment and growth: the case of kenya/liberalisation des taux d'interet, epargne, investissement et croissance: le cas du kenya. Savings and Development, 305-320.

Ouattara, B. (2004). Modelling the long run determinants of private investment in Senegal. Centre for Research in Economic Development and Internat. Trade, University of Nottingham.

Pastor Jr, M., and Sung, J. H. (1995). Private investment and democracy in the developing world. Journal of Economic Issues, 29(1), 223-243.

Pastor, M., and Hilt, E. (1993). Private investment and democracy in Latin America. World Development, 21(4), 489-507.

Persson, T., and Tabellini, G. E. (1990). Macroeconomic policy, credibility and politics (Vol. 38). Taylor and Francis

Pesaran, M.H., Shin, Y., and Smith, R.J. (2001), Bounds Testing Approaches to the Analysis of Level Relationships, Journal of Applied Econometrics, 16, No.3, pp. 289-326.

Phillips, P.C.B., and Perron, P. (1988), Testing For a Unit Root in Time Series Regression, Biometrika, 75, No.2, pp. 335-346.

Porter, M. E. (1998). Cluster and the new economics of competition. 
Porter, M. E. (2000). Location, competition, and economic development: Local clusters in a global economy. Economic development quarterly, 14(1), 15-34.

Ranjan, R. and Kumar, S. (2012). An empirical investigation of the impact of capital inflows on domestic investment in India. Department of Economics, Delhi School of Economics, University of Delhi.

Ribeiro, M.B. and Teixeira, J. R. (2001). An econometric analysis of private-sector investment in Brazil. CEPAL Review 74, 153-166.

Rodrik, D. (2006). Goodbye Washington consensus, hello Washington confusion? A review of the World Bank's economic growth in the 1990s: learning from a decade of reform. Journal of Economic literature, 44(4), 973-987.

Servén, L. (1990). Anticipated real exchange rate changes and the dynamics of investment. PRE Working Paper no. 562, World Bank Publications.

Servén, L. (1998). Macroeconomic uncertainty and private investment in developing countries: An empirical investigation. World Bank Policy Research Working Paper, (2035).

Servén, L. (2003). Real-exchange-rate uncertainty and private investment in LDCs. The Review of Economics and Statistics, Vol. 85, No. 1 (Feb., 2003), pp. 212-218 MIT Press.

Sowa, N.K. (2002). An assessment of poverty reducing policies and programmes in Ghana. Prepared for presentation at a MIMAP Workshop on Assessing Poverty Policies to be held at Rabat, Morocco, January 25-31, sponsored by the IDRC.

Spencer, B. J. (2005). International outsourcing and incomplete contracts. Canadian Journal of Economics/Revue canadienne d'économique, 38(4), 1107-1135.

Stasavage, D. (2002). Private investment and political institutions. Economics and politics, 14(1), 41-63.

Suhendra, I., and Anwar, C. J. (2014). Determinants of private investment and the effects on economic growth in Indonesia. GSTF Journal on Business Review (GBR), 3(3).

Uneze, E. (2010). Testing the impact of foreign aid on domestic private investment in West Africa. African Review of Money Finance and Banking, 59-84.

Van Biesebroeck, J. (2005). Exporting raises productivity in sub-Saharan African manufacturing firms. Journal of International economics, 67(2), 373-391.

World Bank, (2015). World Development Indicators. World Bank: Washington D.C. 


\section{TABLES AND FIGURES}

\section{Table 1: Unit root test results}

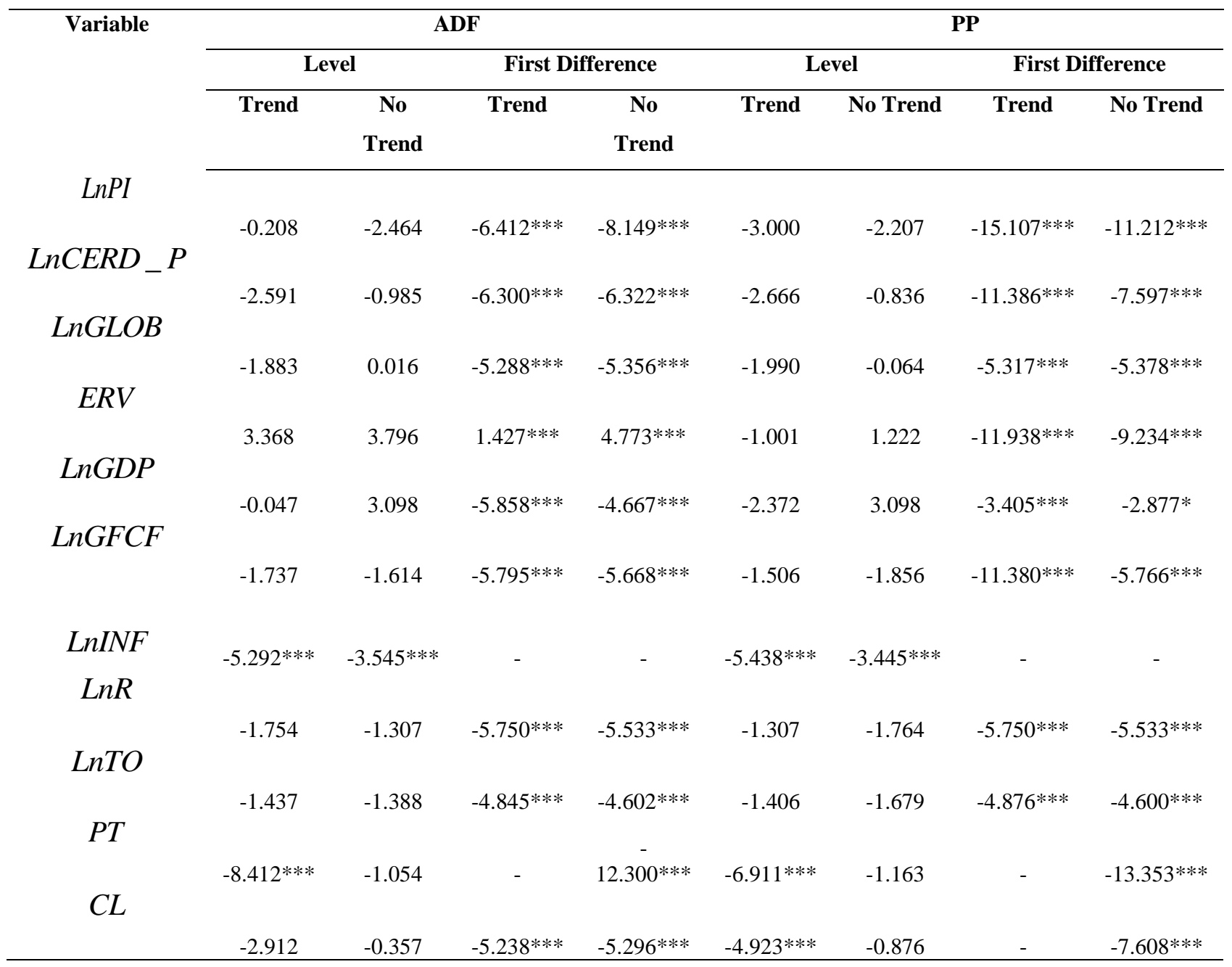

Source: Authors.

Note: $* * *(*)$ indicates rejection of the null hypothesis of unit root at 1 per cent ( 10 per cent) levels of statistical significance. 
Table 2: ARDL bounds test for cointegration relationship

\begin{tabular}{cc}
\hline \multicolumn{3}{c}{ Test-Statistics } \\
\hline Model 1 & Model 2 \\
$3.886249 * *$ & $4.727442 * *$ \\
\hline
\end{tabular}

Source: Authors

Note: ** indicates the rejection of the null hypothesis at 5\% significance level. The ARDL model gives the 95 per cent lower and upper bound values for Models 1 and 2 as 3.4 and 2.14; and 3.3 and 2.14 respectively. 
Table 3: The estimated long-run coefficients using the ARDL approach

\begin{tabular}{|c|c|c|}
\hline Regressor & Model 1 & Model 2 \\
\hline$L_{n C R E D}{ }_{-} P$ & $\begin{array}{l}0.410207 \\
{[0.1126]}\end{array}$ & $\begin{array}{l}0.521864 * \\
{[0.273523]}\end{array}$ \\
\hline $\operatorname{LnGLOB}$ & $\begin{array}{l}2.334140 * \\
{[1.142667]}\end{array}$ & $\begin{array}{c}1.524721 \\
{[0.932777]}\end{array}$ \\
\hline$E R V$ & $\begin{array}{c}-0.751222 * * * \\
{[0.248329]}\end{array}$ & $\begin{array}{c}-0.694563 * * \\
{[0.243097]}\end{array}$ \\
\hline$L n G D P$ & $\begin{array}{c}0.243847 \\
{[1.073820]}\end{array}$ & $\begin{array}{c}0.065024 \\
{[1.068609]}\end{array}$ \\
\hline$L n G F C F$ & $\begin{array}{c}1.606116 * * * \\
{[0.322300]}\end{array}$ & $\begin{array}{c}1.493576 * * * \\
{[0.318937]}\end{array}$ \\
\hline LnINF & $\begin{array}{c}0.053614 \\
{[0.091271]}\end{array}$ & $\begin{array}{c}0.083481 \\
{[0.097253]}\end{array}$ \\
\hline $\operatorname{LnR}$ & $\begin{array}{c}0.499007 \\
{[0.341092]}\end{array}$ & $\begin{array}{c}0.517442 \\
{[0.344762]}\end{array}$ \\
\hline LnTO & $\begin{array}{l}-0.942333 * \\
{[0.316735]}\end{array}$ & $\begin{array}{c}-0.952162 * * \\
{[0.342488]}\end{array}$ \\
\hline$P T$ & $\begin{array}{c}-0.043777 \\
{[0.034192]}\end{array}$ & - \\
\hline$C L$ & - & $\begin{array}{c}0.075662 \\
{[0.122308]}\end{array}$ \\
\hline $\mathrm{C}$ & -11.498586 & -7.638831 \\
\hline
\end{tabular}

Source: Authors

Note: $* * *(* *)(*)$ represent significance at $1 \%, 5 \%$ and $10 \%$ levels of statistical respectively. Standard errors are in parenthesis 
Table 4: The estimated short-run coefficients using the ARDL approach

\begin{tabular}{|c|c|c|}
\hline Regressor & Model 1 & Model 2 \\
\hline$\triangle L n C R E D_{-} P$ & $\begin{array}{c}0.328106 \\
{[0.202654]}\end{array}$ & $\begin{array}{l}0.428502 * \\
{[0.234600]}\end{array}$ \\
\hline$\triangle L n G L O B$ & $\begin{array}{l}1.866973 * \\
{[0.955085]}\end{array}$ & $\begin{array}{c}1.251949 \\
{[0.839576]}\end{array}$ \\
\hline$\triangle E R V$ & $\begin{array}{c}-0.600869 * * * \\
{[0.173367]}\end{array}$ & $\begin{array}{c}-0.570306 * * * \\
{[0.182329]}\end{array}$ \\
\hline$\triangle L n G D P$ & $\begin{array}{c}-4.529775^{* * *} \\
{[1.573725]}\end{array}$ & $\begin{array}{c}-4.770172 * * \\
{[1.717133]}\end{array}$ \\
\hline$\triangle L n G F C F$ & $\begin{array}{c}2.567620 * * * \\
{[0.233645]}\end{array}$ & $\begin{array}{c}2.541662 * * * \\
{[0.269062]}\end{array}$ \\
\hline$\Delta L n I N F$ & $\begin{array}{c}0.042883 \\
{[0.073985]}\end{array}$ & $\begin{array}{c}0.068546 \\
{[0.081728]}\end{array}$ \\
\hline$\Delta \operatorname{LnR}$ & $\begin{array}{c}-0.773781 * * \\
{[0.348985]}\end{array}$ & $\begin{array}{c}-0.732030^{*} \\
{[0.366638]}\end{array}$ \\
\hline$\triangle L n T O$ & $\begin{array}{c}-0.753730 * * \\
{[0.267408]}\end{array}$ & $\begin{array}{c}-0.781821 * * \\
{[0.304202]}\end{array}$ \\
\hline$\triangle P T$ & $\begin{array}{c}-0.035016 \\
{[0.026614]}\end{array}$ & - \\
\hline$\triangle C L$ & - & $\begin{array}{c}0.062126 \\
{[0.101688]}\end{array}$ \\
\hline $\mathrm{ecm}[-1]$ & $\begin{array}{c}-0.7999855^{* * * *} \\
{[0.116480]}\end{array}$ & $\begin{array}{c}-0.821100 * * * \\
{[0.122573]}\end{array}$ \\
\hline $\bar{R}^{2}$ & 0.964850 & 0.962253 \\
\hline F-Stat & $38.00751 * * *$ & $35.29672 * * *$ \\
\hline DW-Stat & 2.286180 & 2.414351 \\
\hline
\end{tabular}

Source: Authors

Note: $* * *, * *$ and $*$ represent significance at $1 \%, 5 \%$ and $10 \%$ respectively. In parenthesis are the standard errors 
Table 5: Model diagnostic and stability tests

\begin{tabular}{ccc}
\hline & Model 1 & Model 2 \\
\hline Serial correlation & 1.033569 & 1.630152 \\
& {$[0.3236]$} & {$[0.2188]$} \\
Normality & 0.307834 & 0.328665 \\
& {$[0.857343]$} & {$[0.848460]$} \\
Heteroskedasticity & 1.778654 & 2.084243 \\
& {$[0.1275]$} & {$[0.1162]$} \\
CUSUM & STABLE & STABLE \\
CUSUMQ & STABLE & STABLE \\
\hline
\end{tabular}

Source: Authors

Note: In parenthesis are probability values 


\section{FIGURES}

\section{MODEL 1}

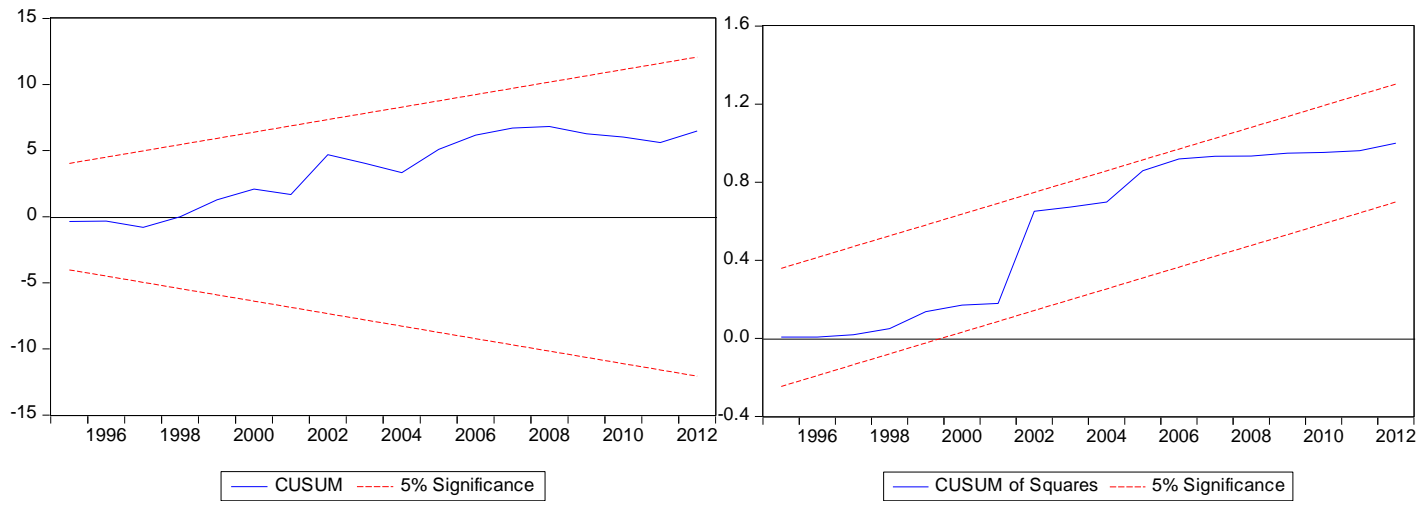

MODEL 2

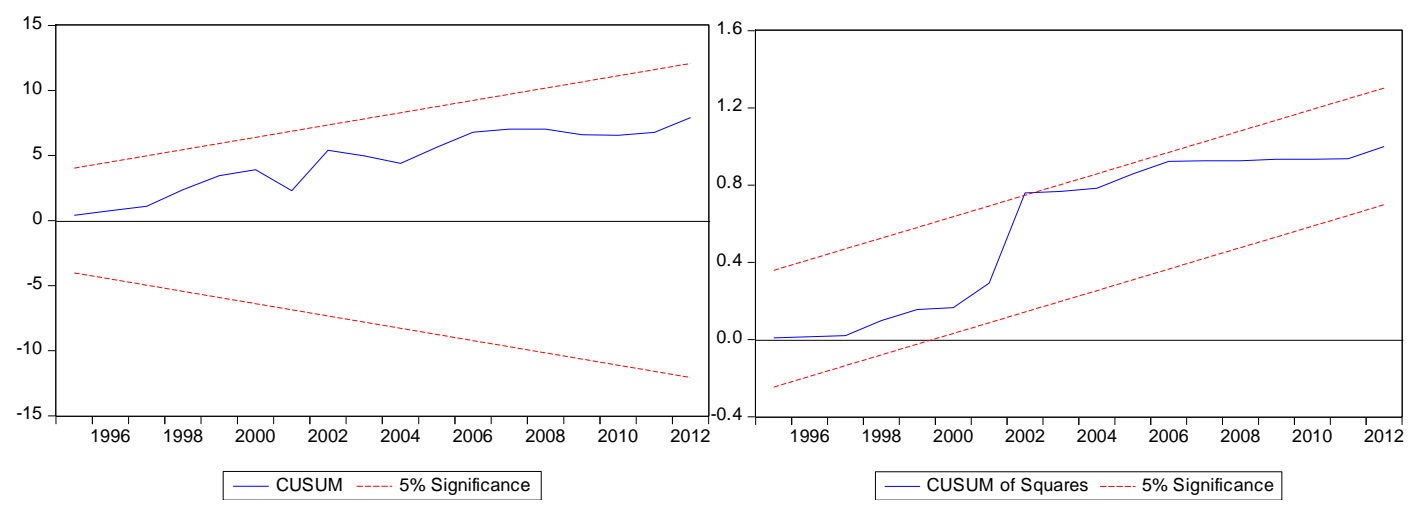

Source: Authors 